\title{
Effects of 1-Methylcyclopropene and Heat Treatments on Ripening and Postharvest Decay in 'Golden Delicious' Apples
}

\author{
Robert A. Saftner, Judith A. Abbott, and William S. Conway \\ Produce Quality and Safety Laboratory, Beltsville Agricultural Research Center, Agricultural Research \\ Service, United States Department of Agriculture, Beltsville, MD 20705 \\ Cynthia L. Barden \\ Fruit Research and Extension Center, Pennsylvania State University, Biglerville, PA 17307
}

AdDitional INDEX words. Botrytis cinerea, Colletotrichum acutatum, fruit quality, ethylene, fruit firmness, Malus sylvestris, MCP, Penicillium expansum, postharvest storage, texture

\begin{abstract}
Prestorage heat, CA storage, and pre- and poststorage treatments with the ethylene action inhibitor, 1methylcyclopropene (MCP), were tested for their efficacy at inhibiting fungal decay and maintaining quality in 'Golden Delicious' apples [Malus sylvestris (L.) Mill. Yellow Delicious Group] stored 0 to 5 months at $0{ }^{\circ} \mathrm{C}$ and 7 days at $20{ }^{\circ} \mathrm{C}$. Before storage in air at $0^{\circ} \mathrm{C}$, preclimacteric fruit were treated with either MCP at a concentration of $1 \mu \mathrm{L} \cdot \mathrm{L}^{-1}$ for $17 \mathrm{hours}$ at $20^{\circ} \mathrm{C}, 38^{\circ} \mathrm{C}$ air for 4 days, MCP plus heat, or left untreated. Some sets of untreated fruit were stored in a controlled atmosphere of $1.5 \mathrm{kPa} \mathrm{O}_{2}$ and $2.5 \mathrm{kPa} \mathrm{CO}_{2}$ at $0{ }^{\circ} \mathrm{C}$ while other sets were removed from cold storage in air after 2.5 or 5 months, warmed to $20^{\circ} \mathrm{C}$, and treated with $1 \mu \mathrm{L} \cdot \mathrm{L}^{-1} \mathrm{MCP}$ for 17 hours. Prestorage MCP, heat, MCP plus heat treatments and CA storage decreased decay severity caused by wound-inoculated Penicillium expansum Link, Botrytis cinerea Pers.:Fr., and Colletotrichum acutatum Simmonds (teleomorph Glomerella acutata J.C. Guerber \& J.C. Correll sp.nov.). Poststorage MCP treatment had no effect on decay severity. Both prestorage MCP treatment and CA storage delayed ripening as indicated by better retention of green peel color, titratable acidity, and Magness-Taylor flesh firmness, and the reduced respiration, ethylene production rates, and volatile levels that were observed upon transferring the fruit to $20{ }^{\circ} \mathrm{C}$. The prestorage MCP treatment delayed ripening more than CA storage. Following 5 months cold storage, the prestorage MCP treatment maintained the shape of the compression force/deformation curve compared with that of fruit at harvest, as did CA storage, but at a lower force profile. The heat treatment had mixed effects on ripening: it hastened loss of green peel color and titratable acidity, but maintained firmness and delayed increases in respiration, ethylene production and volatile levels following cold storage. The MCP plus heat treatment inhibited ripening more than heat treatment alone but less than MCP treatment alone. In one of 2 years, the MCP plus heat treatment resulted in superficial injury to some of the fruit. Results indicated that MCP may provide an effective alternative to CA for reducing decay severity and maintaining quality during postharvest storage of 'Golden Delicious' apples. Prestorage heat to control decay and maintain quality of apples needs further study, especially if used in combination with MCP.
\end{abstract}

Ethylene is known to accelerate ripening and senescence in apple (Malus sylvestris) and other climacteric fruit. Several cycloolefins, including 2,5-norbornadiene and diazocyclopentadiene, have been shown to interact with ethylene receptors and to suppress ethylenemediated ripening responses in apple (Bankenship and Sisler, 1989, 1993), but these substances have not been commercially accepted because of their toxicity and manufacturing concerns (Fan et al., 1999a). A more recently identified member of the gaseous cycloolefin family of ethylene action inhibitors, 1-methylcyclopropene (MCP), suppressed ethylene-mediated ripening of many climacteric fruit including banana (Golding et al., 1998; Sisler and Serek, 1997; Wyllie et al., 1998), pear (Baritelle et al., 2001; Lelièvre et al., 1997), plum (Abdi et al., 1998), tomato (Nakatsuka et al., 1997; Sisler and Serek, 1997), and apple (Baritelle et al., 2001; Fan and Mattheis, 1999; Fan et al., 1999a; Rupasinghe et al., 2000; Watkins et al., 2000). Further, development of superficial scald, soft scald, and other physiological disorders of apple appears to involve ethylene, as MCP prevented or reduced their incidence during storage (Fan et al., 1999b; Watkins et al., 2000).

Received for publication 6 Dec. 2001. Accepted for publication 4 Sept. 2002. The authors wish to thank Michele Auldridge, Prayoon Charoennun, Williard Douglas, Eunhee Park, and Terry Salada for dedicated technical help. Use of a company name or product by the U.S. Department of Agriculture does not imply approval or recommendation of the product to the exclusion of others that also may be suitable.
Compared to other ethylene action inhibitors, MCP binds to the ethylene receptors longer (Sisler et al., 1996), and has been formulated into a powder (Rohm and Haas trade name SmartFresh) that releases MCP when mixed with water.

While MCP has been approved for use on the United Statesgrown 2002 apple crop, there is concern that decreases in ethylene sensitivity (such as by MCP treatment) might adversely affect disease resistance (Bent et al., 1992). Ethylene has been correlated with induction of a wide range of resistance responses, but this does not necessarily mean that ethylene induces resistance. Rather, ethylene has been hypothesized to serve as an ancillary component during host defense, possibly affecting the expression of more phytotoxic compounds (Boller, 1990). When plants are treated with ethylene or its precursors, or are genetically transformed for ethylene insensitivity, disease incidence and severity can be altered or left unaffected depending on the specific plantmicrobe interaction (Bent et al., 1992; Knoester et al., 1998; Lund et al., 1998; Porat et al., 1999). One explanation may be that ethylene-induced plant defense responses are variably offset by ethylene-induced senescence processes (Knoester et al., 1998). In certain nonclimacteric fruit, MCP treatment can increase (Ku et al., 1999; Porat et al., 1999) or have no impact (Mullins et al., $2000)$ on decay severity. In Japanese pear, MCP reduced expression of one of three tested plant defense-related proteins (Itai et al., 2000). 
Three of the most important postharvest pathogens causing decay in apples are Penicillium expansum Link, Botrytis cinerea Pers.:Fr., and Colletotrichum acutatum Simmonds (Rosenberger, 1991; Sutton, 1991). To our knowledge, the effect of MCP on postharvest decay in apples by these pathogens has not been reported.

Another concern about the use of MCP in apples is whether MCP adversely affects the textural characteristics and flavorassociated volatile levels of treated fruit during cold storage and marketing. During the course of our investigation, others reported that MCP inhibited Magness-Taylor softening (Fan et al., 1999a; Rupasinghe et al., 2000; Watkins et al., 2000) and flavor-associated volatile production (Rupasinghe et al., 2000; Song et al., 1997 ) in apples. Variations in the efficacy of MCP have been attributed to cultivar and storage condition differences (Watkins et al., 2000), both of which are associated with the maturity/ ripeness of the fruit at harvest.

Postharvest heat treatments may also be used as a means to modify ripening and alleviate pathological disorders (Klein and Lurie, 1992; Lurie, 1998). Specifically, heating reduced decay severity caused by $B$. cinerea and $P$. expansum in 'Golden Delicious' apples (Fallik et al., 1996; Klein et al., 1997; Lurie et al., 1998). Prestorage heating hastened ripening as indicated by enhanced peel degreening (Klein and Lurie, 1992; Liu, 1978) and lowered acidity (Porritt and Lidster, 1978). On the contrary, prestorage heat delayed ripening as indicated by transiently inhibiting aroma volatile production (Fallik et al., 1997) and maintaining fruit firmness (Klein and Lurie, 1992; Liu, 1978; Porritt and Lidster, 1978).

A combination of heat and MCP may be more effective than either alone, and may complement one another and minimize any individual shortcomings. The purpose of this research was to investigate the efficacy of MCP, heat, MCP plus heat, and $\mathrm{CA}$ storage to maintain quality and inhibit decay in apples.

\section{Materials and Methods}

Fruit. 'Golden Delicious' apples (100 count/box) were harvested in 1997, 1998, and 1999 at the preclimacteric stage [ethylene production $<2 \mathrm{pmol} \cdot \mathrm{kg}^{-1} \cdot \mathrm{s}^{-1}, \mathrm{CO}_{2}$ production $\approx 40$ $\mathrm{nmol} \cdot \mathrm{kg}^{-1} \cdot \mathrm{s}^{-1}$, starch index 3.0 to 4.5 using Cornell generic starch scale 1 to 8 (Blanpied and Silsby, 1992), and Magness-Taylor (MT) firmness $\approx 83 \mathrm{~N}$ ] from a commercial orchard and randomized. Fruit were placed on fruit pack trays and allowed to equilibrate to $20^{\circ} \mathrm{C}$ for $17 \mathrm{~h}$.

MCP APPLICATION AND FRUIT STORAGE. One day after harvest, lots of apples each containing 140 fruit on seven fruit trays were placed in sealed 208-L stainless steel containers containing $200 \mathrm{~g}$ of soda lime and exposed to initial concentrations of 0 or $1 \mu \mathrm{L} \cdot \mathrm{L}^{-1} \mathrm{MCP}$ (EthylBloc; Biotechnologies for Horticulture, Inc., Waltersboro, S.C.) at $20^{\circ} \mathrm{C}$ for $17 \mathrm{~h}$. After MCP treatment, apples were placed on new trays and air equilibrated at $20^{\circ} \mathrm{C}$ for $0 \mathrm{~h}$ (year 1) or $8 \mathrm{~h}$ (years 2 and 3). Untreated fruit were kept in a separate room from MCP-treated fruit to avoid possible contamination by MCP outgassing. On day 2 after harvest, trays of MCP-treated and untreated fruit (replicates by chamber) were placed in separate boxes, five trays per box, lined with perforated polyethylene bags, and stored in air at $0{ }^{\circ} \mathrm{C}$ for up to 5 months at a relative humidity $(\mathrm{RH})$ of $>85 \%$. After 2.5 and 5 months of cold storage in years 1 and 2 of this study, some untreated lots of 140 fruit were warmed to $20{ }^{\circ} \mathrm{C}$ and treated with either 0 or $1.0 \mu \mathrm{L} \cdot \mathrm{L}^{-1}$ of $\mathrm{MCP}$ as described above. Also, on day 2 after harvest, boxes of MCP- treated (years 1 and 3 only) and untreated fruit were heated to $38^{\circ} \mathrm{C}$ for $4 \mathrm{~d}$ in a walk-in chamber. The relative humidity in the chamber was maintained at $>85 \%$ monitored with a hygrothermograph (Belfort Instrument Co., Baltimore, Md.). Fruit were removed from heat after $4 \mathrm{~d}$, and allowed to equilibrate to $20^{\circ} \mathrm{C}$ for $\approx 17 \mathrm{~h}$. On day 7 after harvest, heated fruit were either placed in air storage at $0{ }^{\circ} \mathrm{C}$ or held at $20{ }^{\circ} \mathrm{C}$ for quality analyses.

In addition, $2 \mathrm{~d}$ after harvest, lots of 140 untreated fruit were stored separately in sealed 208-L storage chambers under controlled atmosphere $\left(\mathrm{CA} ; 1.5 \mathrm{kPa} \mathrm{O}_{2}+2.5 \mathrm{kPa} \mathrm{CO}_{2}\right)$ at $0^{\circ} \mathrm{C}$ and $\mathrm{RH}>85 \%$. Storage chamber atmospheres were established within $4 \mathrm{~d}$ of harvest using cylinders of the gas mixture and bubbling the mixture through columns of distilled water. Controlled atmospheres were maintained for up to 5 months.

Analyses of $\mathrm{O}_{\mathbf{2}}, \mathrm{CO}_{2}$, ETHylene, AND MCP. The levels of $\mathrm{CO}_{2}$, $\mathrm{O}_{2}$, and ethylene were measured using gas chromatography (GC) as previously described (Saftner et al., 1999). 1-Methylcyclopropene levels were measured using a GC (Hewlett Packard 5890) fitted with a Hayesep Q column ( $\approx 3 \mathrm{~m} \times 3 \mathrm{~mm})$ and a photoionization detector. The calibration gas for MCP analyses was $1.08 \mu \mathrm{L} \cdot \mathrm{L}^{-1}$ ethylene (year 1) or $1.05 \mu \mathrm{L} \cdot \mathrm{L}^{-1}$ isobutylene (years 2 and 3 ) in air. When ethylene was used as the calibration gas, a correction factor of 2.8 was used to correct for differences in detector sensitivity between isobutylene and ethylene.

ASSESSMENT OF WOUND-INOCULATED DECAY. After 2.5 or 5 months, fruit were removed from $0{ }^{\circ} \mathrm{C}$ storage, warmed to $20{ }^{\circ} \mathrm{C}$, then wound-inoculated with the decay-causing pathogens, $P$. expansum Link, B. cinerea Pers.:Fr., or C. acutatum Simmonds. For pathogen inoculation, up to 90 fruit from each treatment were wounded on four sides to a depth of $2 \mathrm{~mm}$ by pressing the fruit down on a nail head ( $2 \mathrm{~mm}$ in diameter). The wounded fruit from each treatment were divided into 30 -fruit subsamples and inoculated by pipetting $20 \mu \mathrm{L}$ of freshly prepared conidial suspension (spores of $B$. cinerea, $P$. expansum, or $C$. acutatum at $1 \times 10^{5} \cdot \mathrm{mL}^{-1}$ ) into each wound site. All pathogens were isolated from naturally infected apple fruit and maintained on potato dextrose agar. Apples were rated for decay incidence (percentage of lesions with decay) and for decay severity by measuring the surface diameter of the decayed area as the mean of its width and length after a 7- to 14d period at $20^{\circ} \mathrm{C}$.

Assessment OF FRUIT QUALITY. Respiration and ethylene production rates of MCP-treated and untreated fruit were measured every $8 \mathrm{~h}$ during a 2 - or 7 -d period at $20^{\circ} \mathrm{C}$ using an automated system (Izumi et al., 1996). Three five-fruit replications were measured after 2.5, 3.5 (untreated fruit only), and 5 months cold storage. Respiration and ethylene production rates before cold storage are means of 18 measurements over $2 \mathrm{~d}$ from three fivefruit replications; the remainder are means of 63 measurements over $7 \mathrm{~d}$ from three five-fruit replications. Carbon dioxide evolution and ethylene production are reported as $\mathrm{nmol} \cdot \mathrm{kg}^{-1} \cdot \mathrm{s}^{-1}$ and $\mathrm{pmol} \cdot \mathrm{kg}^{-1} \cdot \mathrm{s}^{-1}$, respectively.

Peel color, MT firmness and compression firmness, soluble solids content (SSC), titratable acidity (TA), and total volatile abundance were measured on the same lots of fruit following 0 , 2.5 and 5 months cold storage plus $7 \mathrm{~d}$ at $20^{\circ} \mathrm{C}$.

Magness-Taylor firmness was measured with an electronic fruit firmness tester (model EPT-1; Lake City Technical Products, Kelowna, B.C., Canada) set in the MT-mode and interfaced to a personal computer. Magness-Taylor firmness (bioyield force) was measured at two opposite points on the equator of each fruit after removing a thin slice of peel from each site. For compression firmness (force/deformation tests), a radial cylinder of apple flesh 
was removed at the equator using a 15 -mm-diameter cork borer. A slice $3 \mathrm{~mm}$ thick including the peel was discarded and the next $10-\mathrm{mm}$ segment was tested in axial compression. The sample was compressed between flat plates at $2 \mathrm{~mm} \cdot \mathrm{s}^{-1}$ to a final height of 2.5 $\mathrm{mm}$ (75\% compression). The force/deformation curve was analyzed for various forces, slopes, and areas (Abbott et al., 1984).

Soluble solids content and TA were determined using freshly prepared juice. Individual fruit were ground in an electric juice extractor. Soluble solids content was measured using a digital, temperature-compensated refractometer (model PR-101; Atago Co. Tokyo, Japan), and TA, expressed as malic acid, was determined by titrating 10-mL juice samples with $1.0 \mathrm{M} \mathrm{KOH}$ to $\mathrm{pH} 8.2$ (Mitcham and Kader, 1996).

Analysis of volatile abundance using a solid-phase microextration (SPME, Supelco Co., Bellefonte, Pa.) technique and gas chromatography was performed as described previously (Saftner, 1999). Constructing calibration curves for each volatile analyte in each apple sample is not feasible and thus total volatile abundance is reported in FID area response units of pA rather than absolute amounts of individual analytes. Samples for volatile analyses were collected from treated and untreated fruit after a 7 d period at $20{ }^{\circ} \mathrm{C}$ following 0 to 5 months storage in air or $\mathrm{CA}$ at $0{ }^{\circ} \mathrm{C}$.

Statistical analyses. The experimental design was a randomized complete block with three replications. In the first year of experimentation, treatments were arranged in a $5 \times 3$ factorial: [control (untreated, air-stored), CA, MCP, heat, and heat plus $\mathrm{MCP}] \times\left[0,2.5\right.$, or 5 month storage at $\left.0{ }^{\circ} \mathrm{C}\right]$. In the second year, treatments were arranged in a $4 \times 3$ factorial: [control, $\mathrm{CA}, \mathrm{MCP}$, and heat treatment $] \times\left[0,2.5\right.$, or 5 month storage at $\left.0^{\circ} \mathrm{C}\right]$. In the third year, treatments were arranged in a $4 \times 3$ factorial: [control, $\mathrm{MCP}$, heat, and MCP plus heat $] \times[0,2.5$, or 5 month storage at $0{ }^{\circ} \mathrm{C}$ ]. Also, in the first 2 years, a poststorage treatment with MCP was evaluated for its ability to retard ripening and maintain disease resistance during $7 \mathrm{~d}$ at $20^{\circ} \mathrm{C}$. Unless stated otherwise, data are presented from the first year and are representative of data collected in the other 2 years.

Data were analyzed by analysis of variance (ANOVA) within storage times to test for treatment effects. Means separation was tested by Tukey's HSD. Additionally, some treatment comparisons were made using a priori contrasts (SAS, 1999). Unless stated otherwise, only results significant at $\alpha=0.05$ are discussed.

Table 1.Effects of 1-methylcyclopropene, heat, and controlled atmosphere storage treatments on wound-inoculated decay severity in 'Golden Delicious' apples following 5 months storage at $0{ }^{\circ} \mathrm{C}$ and $7 \mathrm{~d}$ at $20^{\circ} \mathrm{C}$.

\begin{tabular}{lccc}
\hline & \multicolumn{4}{c}{ Lesion size $(\mathrm{mm})^{\mathrm{z}}$} \\
\cline { 2 - 4 } Treatment & B. cinerea & P. expansum & C. acutatum \\
\hline Prestorage treatments of preclimacteric fruit & $43.0 \mathrm{a}^{\mathrm{y}}$ & $40.2 \mathrm{a}$ & $35.4 \mathrm{a}$ \\
Control & $26.8 \mathrm{c}$ & $25.8 \mathrm{c}$ & $27.4 \mathrm{c}$ \\
CA & $28.4 \mathrm{c}$ & $33.0 \mathrm{~b}$ & $27.8 \mathrm{c}$ \\
MCP & $38.5 \mathrm{~b}$ & $37.1 \mathrm{ab}$ & $31.4 \mathrm{~b}$ \\
Heat & $36.3 \mathrm{~b}$ & $35.0 \mathrm{~b}$ & $32.0 \mathrm{~b}$ \\
MCP + Heat & $44.1 \mathrm{a}$ & $40.4 \mathrm{a}$ & $37.1 \mathrm{a}$ \\
Poststorage treatments of postclimacteric fruit & & \\
Control & $42.7 \mathrm{a}$ & $39.9 \mathrm{a}$ & $35.3 \mathrm{a}$ \\
MCP
\end{tabular}

${ }^{\mathrm{z}}$ Data are reported as the mean of 240 lesion readings from three 10 -fruit replications.

${ }^{\mathrm{y}}$ Means in the same column followed by the same letter are not significantly different by Tukey's HSD $(\alpha=0.05)$.

\section{Results}

DECAY INCIDENCE AND SEVERITY. Decay severity in fruit woundinoculated with $B$. cinerea, $P$. expansum, and $C$. acutatum was reduced between $18 \%$ and $38 \%$ when fruit were treated with MCP at harvest or were cold stored in CA (Table 1). Heat treatment also inhibited decay severity but was less effective than prestorage MCP treatment or CA storage. Similar results were observed following 2.5 months cold storage. None of the treatments used in this study had any effect on decay incidence in woundinoculated fruit (data not shown). In year 1 but not 3 of this study, prestorage MCP plus heat treatment resulted in some fruit having a surface injury resembling superficial scald that was not observed in fruit treated with MCP or heat alone. Poststorage MCP treatment had no effect on wound-inoculated decay severity (Table 1).

RESPIRATION AND ETHYLENE PRODUCTION. Immediately following the heat treatment, there was a 2.6-fold increase in respiration rate (Fig. 1a) and ethylene production was induced $(\alpha=0.05)$, although not enough to be visible in Fig. 1b. 1-Methylcyclopropene treatment before the heat treatment prevented the heat-induced increase in respiration and ethylene production rates. However, compared to untreated fruit, heat treatment generally inhibited respiration and ethylene production rates measured during $7 \mathrm{~d}$ at
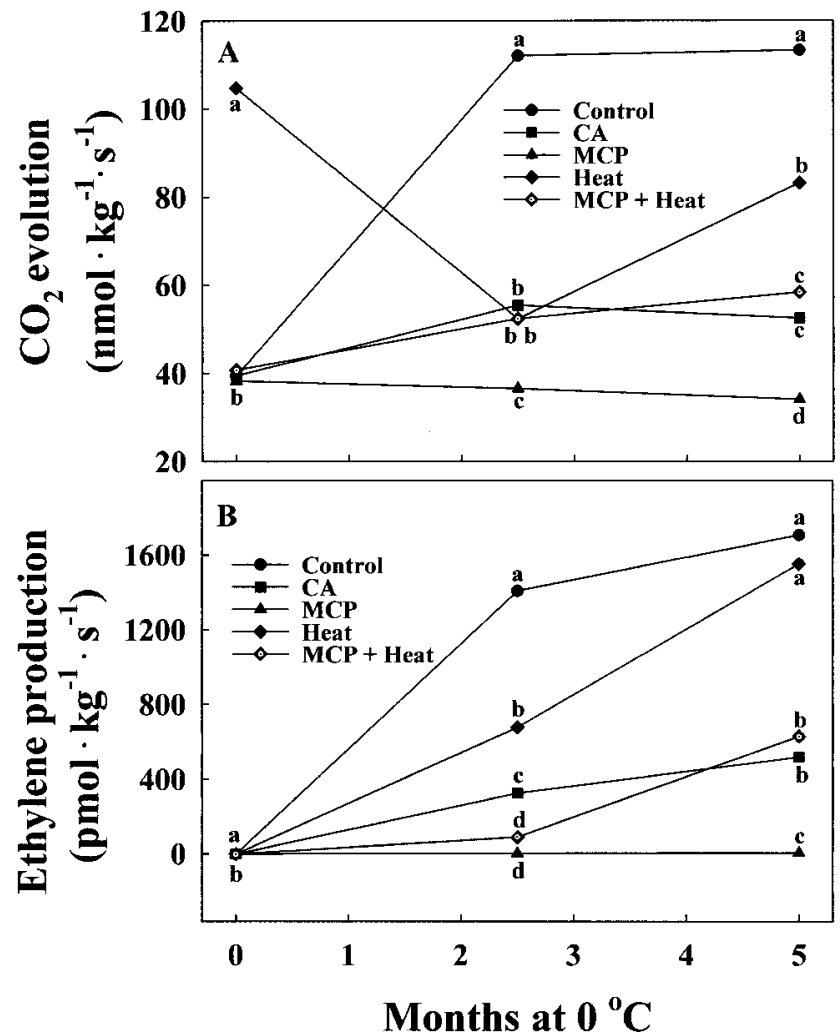

Fig. 1. Effects of prestorage MCP, heat, controlled atmosphere and air treatments on respiration (panel A) and ethylene (panel B) production rates in 'Golden Delicious' apples. Initial respiration and ethylene production rates are means of 18 measurements over $2 \mathrm{~d}$ from three five-fruit replications; the remainder are means of 63 measurements over $7 \mathrm{~d}$ from three five-fruit replications. Measurements were done at $20^{\circ} \mathrm{C}$. Control $=$ cold storage in air; $\mathrm{CA}=$ cold storage in a controlled atmosphere of $1.5 \mathrm{kPa} \mathrm{O}_{2}$ and $2.5 \mathrm{kPaCO}_{2} ; \mathrm{MCP}=$ prestorage $\mathrm{MCP}$ treatment for $17 \mathrm{~h}$ with an initial MCP concentration of $1 \mu \mathrm{L} \cdot \mathrm{L}^{-1}$, cold storage in air; heat $=$ heat treatment for $4 \mathrm{~d}$ at $38^{\circ} \mathrm{C}$ followed by cold storage in air; $\mathrm{MCP}+$ heat = prestorage treatment with MCP, then with heat, cold storage in air. Within columns, symbols labeled with the same letter are not significantly different at $\alpha=0.05$ using Tukey's HSD. 
Table 2. Effects of poststorage1-methylcyclopropene treatment on 'Golden Delicious' apples: respiration and ethylene production rates during 7 d at $20^{\circ} \mathrm{C}$ after removal from cold storage and volatile abundance, MT firmness, and peel color on day 7.

\begin{tabular}{|c|c|c|c|c|c|c|}
\hline Treatment & $\begin{array}{l}\text { Time in } \\
\text { cold } \\
\text { storage }^{\mathrm{z}} \\
\text { (months) }\end{array}$ & $\begin{array}{c}\mathrm{CO}_{2} \\
\text { evolved }^{\mathrm{y}} \\
\left(\mathrm{nmol} \cdot \mathrm{kg}^{-1} \cdot \mathrm{s}^{-1}\right)\end{array}$ & $\begin{array}{c}\text { Ethylene } \\
\text { production } \\
\left(\mathrm{pmol} \cdot \mathrm{kg}^{-1} \cdot \mathrm{s}^{-1}\right)\end{array}$ & $\begin{array}{c}\text { Volatile } \\
\text { abundance }^{\mathrm{x}} \\
\left(\mathrm{pA} \cdot 10^{3}\right)\end{array}$ & $\begin{array}{c}\text { MT } \\
\text { firmness }^{\mathrm{w}} \\
(\mathrm{N})\end{array}$ & $\begin{array}{l}\text { Peel } \\
\text { color }^{w} \\
\left(a^{*}\right)\end{array}$ \\
\hline \multicolumn{7}{|l|}{ Year 1} \\
\hline Control & 2.5 & $101 \mathrm{a}^{\mathrm{v}}$ & $1,080 \mathrm{a}$ & $3.90 \mathrm{a}$ & $49.6 \mathrm{a}$ & $-10.03 a$ \\
\hline MCP & 2.5 & $73 \mathrm{~b}$ & $261 \mathrm{~b}$ & $1.41 \mathrm{~b}$ & $51.9 \mathrm{a}$ & $-10.89 b$ \\
\hline Control & 5 & $104 \mathrm{a}$ & $1,344 \mathrm{a}$ & $6.64 \mathrm{a}$ & $46.3 \mathrm{a}$ & $-8.70 \mathrm{a}$ \\
\hline MCP & 5 & $88 \mathrm{~b}$ & $1,103 \mathrm{~b}$ & $3.81 \mathrm{~b}$ & $47.2 \mathrm{a}$ & $-9.90 \mathrm{~b}$ \\
\hline \multicolumn{7}{|l|}{ Year 2} \\
\hline Control & 2.5 & $129 \mathrm{a}$ & $1,111 \mathrm{a}$ & $3.33 \mathrm{a}$ & $52.5 \mathrm{a}$ & $-5.26 \mathrm{a}$ \\
\hline $\mathrm{MCP}$ & 2.5 & $83 \mathrm{~b}$ & $187 \mathrm{~b}$ & $0.83 \mathrm{~b}$ & $54.9 \mathrm{a}$ & $-6.53 b$ \\
\hline Control & 5 & $137 \mathrm{a}$ & $1,589 \mathrm{a}$ & $3.51 \mathrm{a}$ & $46.5 \mathrm{a}$ & $-2.00 \mathrm{a}$ \\
\hline $\mathrm{MCP}$ & 5 & $109 \mathrm{~b}$ & $1,358 \mathrm{~b}$ & $1.92 \mathrm{~b}$ & $48.2 \mathrm{a}$ & $-3.95 b$ \\
\hline
\end{tabular}

${ }^{\mathrm{z} F r u i t}$ following 2.5 and 5 months cold storage were climacteric and postclimacteric, respectively.

y Data are reported as the mean of 63 readings collected over $7 \mathrm{~d}$ from each of three five-fruit replications.

xData are reported as the mean of nine readings collected from each of nine three-fruit replications.

wData are reported as the mean of 60 readings from each of three 10-fruit replications.

'Means in the same column for each storage period from each year followed by the same letter are not significantly different by Tukey's HSD ( $\alpha=$ $0.05)$.

$20{ }^{\circ} \mathrm{C}$ following cold storage (Fig. 1). Both CA storage and prestorage MCP treatment (without and with heat treatment) had more persistent inhibitory effects on respiration and ethylene production rates than heat treatment alone. Prestorage MCP treatment essentially prevented the climacteric rise in respiration and ethylene production rates during storage. A climacteric peak in respiration and ethylene production rates was observed following 3.5 months cold storage in untreated fruit (data not shown). Poststorage MCP treatment (Table 2) was less effective at reducing respiration and ethylene production rates during $20^{\circ} \mathrm{C}$ storage than prestorage MCP treatment (Fig. 1).

FirmNEss. Prestorage MCP treatment maintained MT firmness during storage at 0 and $20^{\circ} \mathrm{C}$ (Fig. 2). Controlled atmosphere storage also inhibited the loss of MT firmness but was less effective than prestorage MCP. While heat treatment of MCPtreated and untreated fruit increased loss of MT firmness before

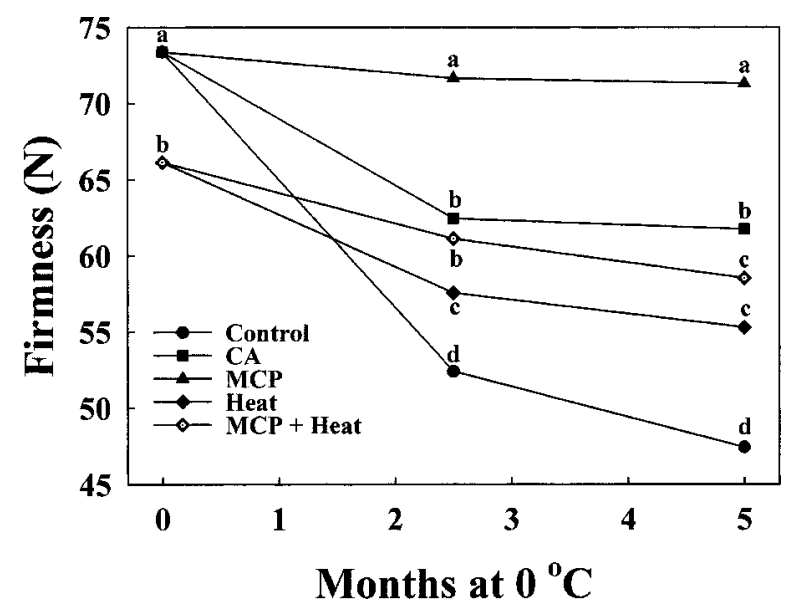

Fig. 2. Effect of prestorage MCP, heat, controlled atmosphere and air treatments on Magness-Taylor (MT) firmness in 'Golden Delicious' apples. Measurements were done after $7 \mathrm{~d}$ at $20^{\circ} \mathrm{C}$ following 0 to 5 months storage at $0{ }^{\circ} \mathrm{C}$. At harvest, fruit were preclimacteric; refer to Fig. 1 to determine physiological stage following 2.5 and 5 months cold storage. Each point is the mean of 60 readings from three 10-fruit replications. Treatments are described in the caption to Fig. 1 . Within columns, symbols labeled with the same letter are not significantly different at $\alpha=0.05$ using Tukey's HSD. cold storage (presumably occurring during the 4-d heat treatment), heated fruit were firmer than untreated fruit following 2.5 or 5.0 months cold storage. Following 2.5 and 5 months cold storage, prestorage MCP treatment maintained the shape of the

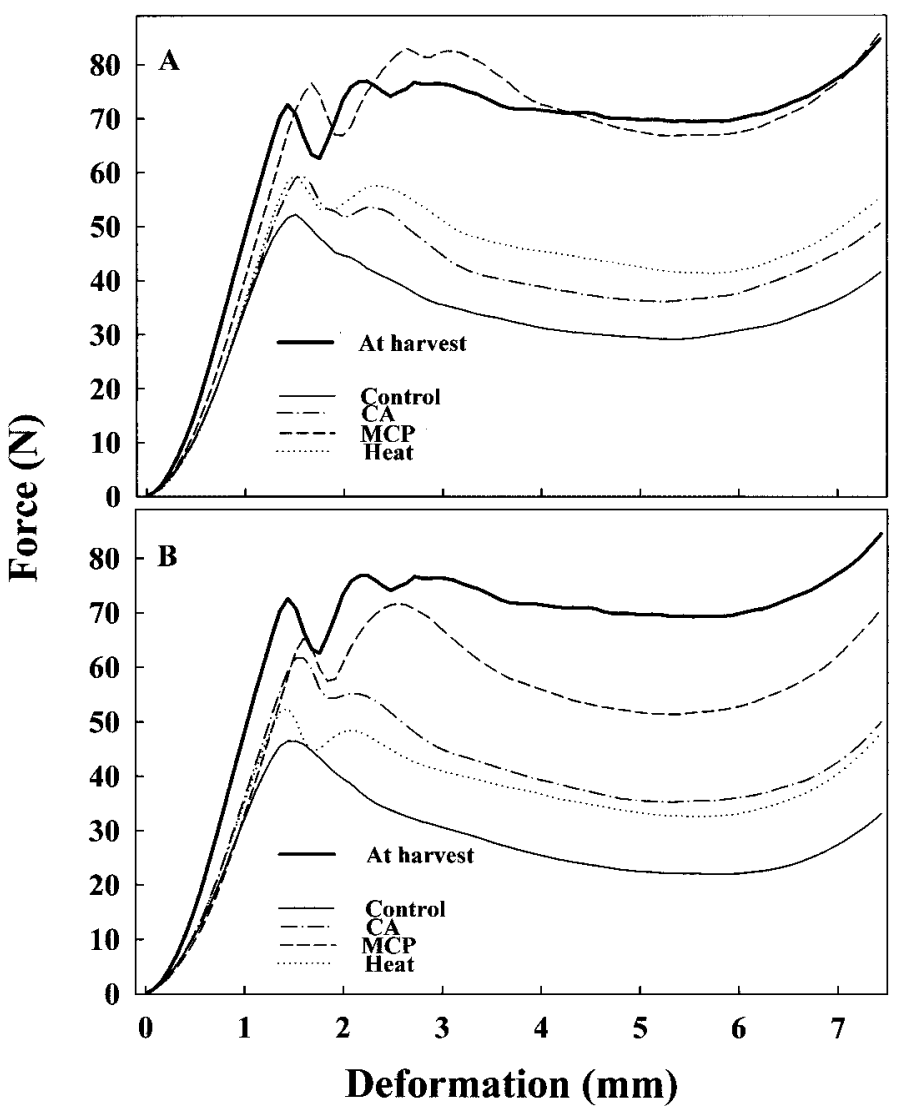

Fig. 3. Compression force/deformation curves for control fruit at harvest and for control, CA-stored, and prestorage MCP and heat-treated fruit following 2.5 (panel A) or 5 (panel B) months storage at $0^{\circ} \mathrm{C}$ and $7 \mathrm{~d}$ at $20^{\circ} \mathrm{C}$. At harvest, fruit were preclimacteric; refer to Fig. 1 to determine physiological stage following 2.5 and 5 months cold storage. Each curve is a composite of 60 readings from three replications of 20 fruit. Treatments are described in the caption to Fig. 1. 
compression force and deformation curves similar to the curves from fruit at harvest (Fig. 3). Heat treatment or CA storage also maintained similar curve shapes but at lower force profiles than MCP treatment (Fig. 3). The control fruit force/deformation curves lacked the secondary peaks around 2 to $3 \mathrm{~mm}$ deformation following the initial tissue failure. Poststorage MCP treatment had little effect on maintaining MT firmness during storage at 20 ${ }^{\circ} \mathrm{C}$ (Table 2).

Peel Color. Heat treatment of MCP-treated and untreated fruit initially decreased peel greenness and this effect persisted through 5 months storage at $0{ }^{\circ} \mathrm{C}$ and a 7 -d period at $20^{\circ} \mathrm{C}$ (Fig. 4). Prestorage MCP treatment without heat or CA storage decreased peel degreening during storage at 0 and $20{ }^{\circ} \mathrm{C}$, with prestorage MCP being more effective. A poststorage MCP treatment was also effective at maintaining green peel color (Table 2). The loss of peel greenness after storage at 0 and $20{ }^{\circ} \mathrm{C}$ corresponded to increases in peel yellowing, i.e., increasing $b^{*}$ values. Peel lightness, $L^{*}$, was not significantly affected by any treatment (data not shown).

Titratable ACIDITY AND SOLUble Solids. Heat treatment initially decreased titratable acidity, but application of MCP before heat treatment essentially prevented loss of acidity (Fig. 5). The lower titratable acidity in heat-treated fruit persisted during storage. Titratable acidity was greater in prestorage MCP-treated and in CA-stored fruit than in untreated fruit throughout storage. There were no differences in titratable acidity between poststorage MCP-treated and untreated fruit (data not shown).

There were no differences among any pre- or poststoragetreated fruit in soluble solids (data not shown). Mean soluble solids among all treatments and storage periods were between $13.1 \%$ and $15.2 \%$.

Total Volatile ABUNDAnce. Heat treatment alone increased volatile abundance before cold storage; however, when fruit had been treated with MCP prior to the heat treatment, no volatile increase was noted (Fig. 6). The heat treatment transiently inhibited volatile abundance during storage at 0 and $20^{\circ} \mathrm{C}$, whereas the prestorage MCP plus heat treatment had a more persistent inhibitory effect. Both prestorage MCP treatment and CA storage inhibited the climacteric-associated increase in volatile abun-

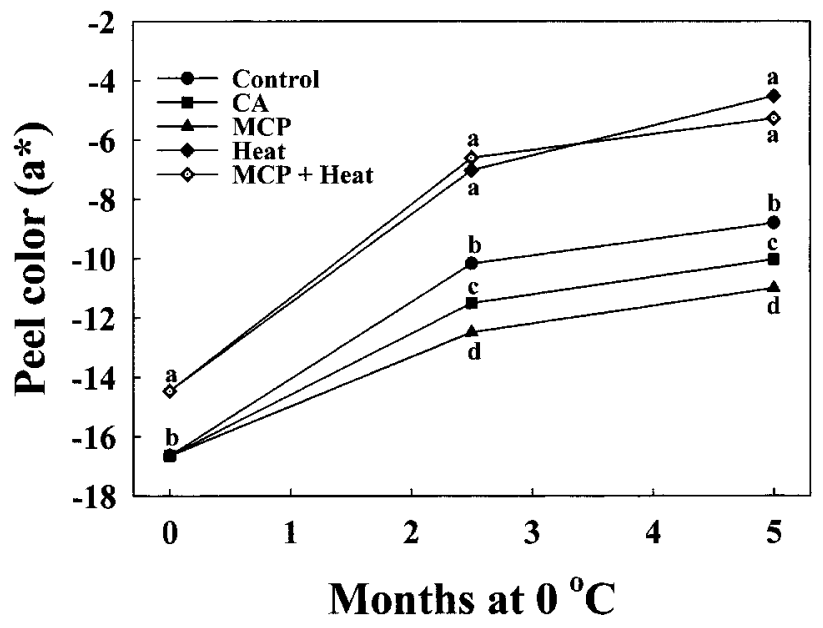

Fig. 4. Effect of prestorage MCP, heat, and controlled atmosphere treatment on peel greenness in 'Golden Delicious' apples. Measurements were done after 7 d at $20{ }^{\circ} \mathrm{C}$ following 0 to 5 months storage at $0{ }^{\circ} \mathrm{C}$. At harvest, fruit were preclimacteric; refer to Fig. 1 to determine physiological stage following 2.5 and 5 months cold storage. More negative a* values indicate a greener peel color. Each point is the mean of 60 readings from three 10 -fruit replications. Treatments are described in the caption to Fig. 1. Within columns, symbols labeled with the same letter are not significantly different at $\alpha=0.05$ using Tukey's HSD. dance during storage. Poststorage MCP treatment also inhibited volatile levels during storage at $20^{\circ} \mathrm{C}$ (Table 2).

\section{Discussion}

Prestorage $\mathrm{MCP}$, but not heat, treatment followed by storage in air at 0 and $20^{\circ} \mathrm{C}$ was generally as efficient as CA storage at inhibiting decay severity caused by three major postharvest pathogens of apples, and was generally more efficient than CA storage at maintaining fruit quality and storage life of 'Golden Delicious' apples. Only ethylene-mediated ripening characteristics were inhibited by the prestorage MCP treatment. It inhibited firmness loss (Fig. 3b) and peel degreening (Fig. 4) better than CA storage and inhibited the decrease in acidity (Fig. 5) as well as CA storage. Poststorage MCP treatment was less effective than the same treatment applied before storage at maintaining quality during storage at $20^{\circ} \mathrm{C}$ and had no inhibitory effects on decay severity.

While MCP has been approved for use on United States-grown apples for the 2002 season, an MCP dosage that would reliably delay, but not prevent, ripening and associated aroma volatile production and peel degreening has not been well established for all cultivars. The efficacy of MCP to inhibit ripening of apples is affected by, among other factors, MCP dosage, cultivar and fruit maturity, and storage conditions (Fan et al., 1999a; Rupasinghe et al., 2000; Watkins et al., 2000). In our study, MCP was applied to both preclimacteric and climacteric fruit at a concentration of $1 \mu \mathrm{L} \cdot \mathrm{L}^{-1}$, but the vapor concentration decreased during the treatment period to $\approx 0.4 \mu \mathrm{L} \cdot \mathrm{L}^{-1}$. 1-Methylcyclopropene adsorbed to both the fruit and the packing trays (Verona, personal communication) causing the vapor concentration within the treatment chambers to decrease in a curvilinear pattern during incubation. Despite this complication, and except for peel degreening, MCP prestorage treatment under the present conditions essentially prevented ripening during storage. The applied dosage may have been excessive for 'Golden Delicious' apples intended for the fresh market because MCP inhibited quality-associated volatile development and peel degreening. For processing, however, this dosage is probably satisfactory since the green peel of MCP-

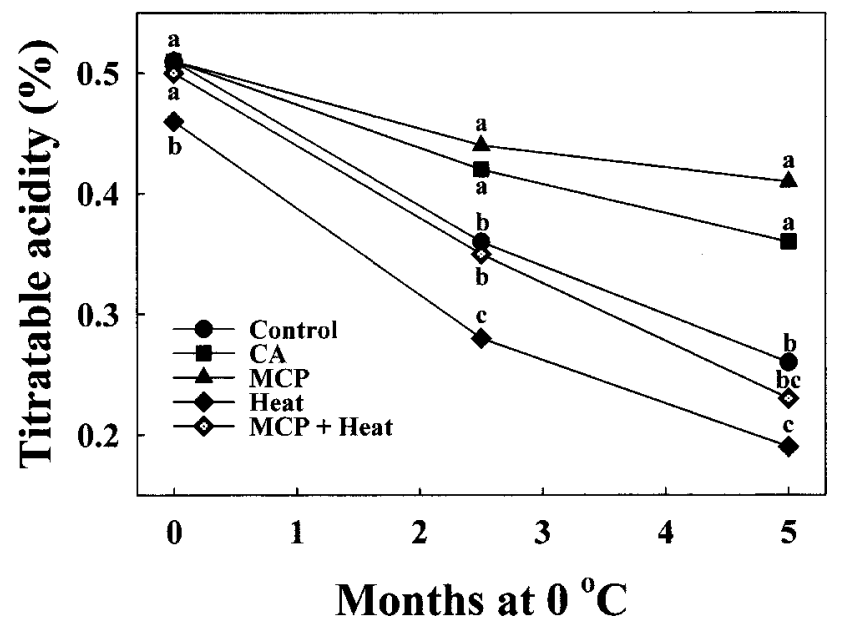

Fig. 5. Effect of prestorage MCP, heat, controlled atmosphere and air treatments on titratable acidity in 'Golden Delicious' apples. Measurements were done after $7 \mathrm{~d}$ at $20^{\circ} \mathrm{C}$ following 0 to 5 months storage at $0{ }^{\circ} \mathrm{C}$. At harvest, fruit were preclimacteric; refer to Fig. 1 to determine physiological stage following 2.5 and 5 months cold storage. Each point is the mean of nine readings from nine threefruit samples collected from three 10-fruit replications. Treatments are described in the caption to Fig. 1. Within columns, symbols labeled with the same letter are not significantly different at $\alpha=0.05$ using Tukey's HSD. 


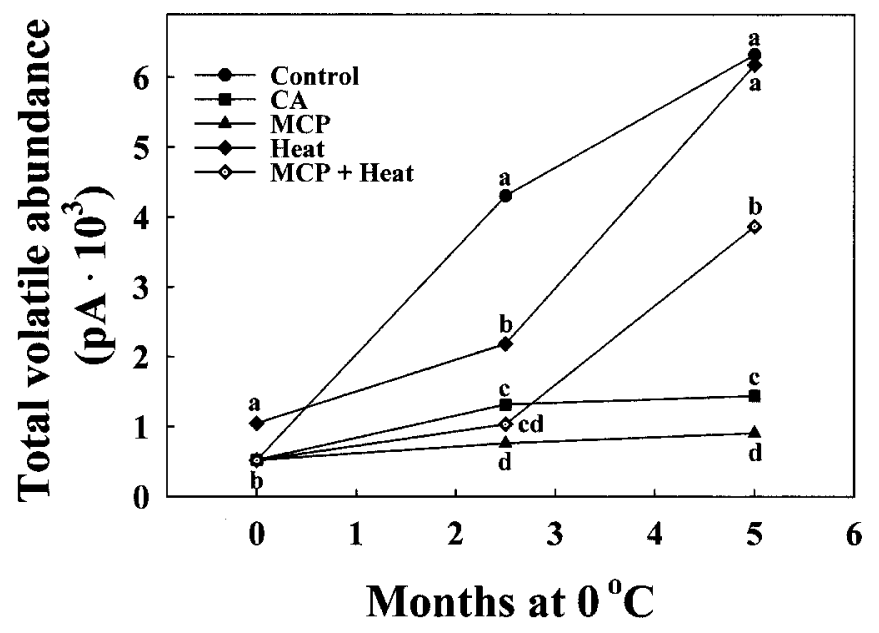

Fig. 6. Effect of prestorage MCP, heat, controlled atmosphere and air treatments on total volatile levels in 'Golden Delicious' apples. Measurements were done after $7 \mathrm{~d}$ at $20^{\circ} \mathrm{C}$ following 0 to 5 months storage at $0{ }^{\circ} \mathrm{C}$. At harvest, fruit were preclimacteric; refer to Fig. 1 to determine physiological stage following 2.5 and 5 months cold storage. Each point is the mean of nine readings from nine threefruit samples collected from three 10-fruit replications. Treatments are described in the caption to Fig. 1. Within columns, symbols labeled with the same letter are not significantly different at $\alpha=0.05$ using Tukey's HSD.

treated apples may be removed during processing and the reduced aroma-associated volatile production could be counteracted by adding apple flavors or essences to the final product. It is not known whether ripening of the MCP-treated fruit would have occurred following a longer storage period. In contrast, the same MCP dosage applied after storage at $0{ }^{\circ} \mathrm{C}$ to climacteric fruit was less effective at inhibiting ripening and had no effect on decay severity (Table 2). Since MCP is a competitive inhibitor of ethylene binding to its receptor, an MCP concentration higher than $1 \mu \mathrm{L} \cdot \mathrm{L}^{-1}$ may be needed to effectively maintain fruit quality in poststorage ethylene-producing fruit. During the initial stage of our study, Song et al. (1997) reported that treating preclimacteric 'Golden Delicious' apples with MCP at $0.5 \mu \mathrm{L} \cdot \mathrm{L}^{-1}$ for $12 \mathrm{~h}$ at 23 ${ }^{\circ} \mathrm{C}$ prevented climacteric respiration, ethylene production, and climacteric-associated volatile production in fruit stored for up to $21 \mathrm{~d}$ at room temperature after treatment. However, MCP application at $2 \mu \mathrm{L} \cdot \mathrm{L}^{-1}$ for $7 \mathrm{~h}$ at 20 to $25^{\circ} \mathrm{C}$ to 'McIntosh' apples that were early climacteric at the time of commercial harvest delayed, but did not stop, ripening (Watkins et al., 2000). Successful commercial utilization of MCP will require an understanding of the relationships between MCP dosage, cultivar and maturity level of the fruit used, and storage conditions (Watkins et al., 2000). At present, our knowledge of the efficacy of MCP in 'Golden Delicious' apples is not detailed enough to assure against over- or underdosing. To guard against overdosing with MCP, it may be advisable to apply MCP to fruit at the early climacteric stage when MCP could compete with climacteric ethylene for binding to the ethylene receptor. Alternatively, mixtures of MCP and ethylene could be applied to preclimacteric fruit to reduce the likelihood of MCP overdosing. Treatment with MCP plus heat may be another way to reduce the efficacy of MCP in that MCP plus heat treatment inhibited ripening less than MCP treatment alone (Figs. 1-3, 5-6). Lowering the MCP concentration or incubation time to control the efficacy of MCP can be problematic in that there is a narrow difference between an MCP dosage that does not affect ripening characteristics and one that prevents ripening (Fan et al., 1999a).

In cases where MCP prevents climacteric respiration and ethylene production, it also prevents ethylene-induced fruit softening, at least during 5 months storage at $0{ }^{\circ} \mathrm{C}$ and $7 \mathrm{~d}$ at $20^{\circ} \mathrm{C}$ (Fig. 2). That textural characteristics were maintained well by MCP during storage is supported by our finding that the shape of the compression force/deformation curve of MCP-treated fruit after 5 months cold storage was similar to that of fruit at harvest (Fig. 3). The effect on textural quality of the shape of the initial peak or of multiple peaks (Fig. 3) has not been established. We speculate that apple tissue having an early fracture and early maximum force might be perceived as crisp whereas one with a late maximum would be tough. Such detailed textural attributes can only be investigated using extensively trained sensory panels. Sensory textural changes may have occurred in MCP-treated fruit during storage, but were not detected with the instrumental method used in this study (Harker et al., 2002a). At present, while the effect of MCP treatment on sensory textural characteristics has not been reported, MCP prevented ethylene-induced softening in our study.

The MCP dosage and time of application may also play an important role in controlling decay severity in apple. When MCP was applied before, but not after, cold storage it decreased woundinoculated decay severity caused by three major postharvest pathogens of apple. These results are in contrast to MCP treatment of nonclimacteric oranges (Porat et al., 1999) and strawberries (Ku et al., 1999) where MCP increased decay severity. An explanation for our observation of MCP-inhibited decay severity is that MCP had a greater inhibitory effect on ethylene-induced senescence and associated loss of natural disease resistance than on ethylene-induced induction of plant defense responses. In contrast, when apples are drought stressed and/or heat stressed after harvest, MCP had no effect on P. expansum-induced decay severity (Leverentz, personal communication). In our study, the efficacy of MCP to decrease decay severity was counteracted by subsequent heat treatment (Table 1). Regardless of the mechanism involved, MCP decreased decay severity under the conditions present in this study.

Immediately after the 4-d heat treatment, respiration and ethylene production rates and volatile levels increased; and firmness, titratable acidity, and green peel color decreased relative to that in untreated fruit, indicating that the treatment itself initially enhanced ripening. Unlike prestorage MCP treatment or CA storage, heat only transiently inhibited respiration, ethylene production, and quality-associated volatile levels during storage. Heat was less effective than prestorage MCP treatment or CA storage at maintaining flesh firmness and decreasing decay severity during storage. Various heat treatments of apples have previously been shown to maintain flesh firmness and decrease decay severity during cold storage (Lurie, 1998; Lurie et al., 1998). However, heat treatments have not been accepted commercially primarily because of the logistics and costs associated with heating and then cooling large quantities of fruit, even though it has potential as a reliable method to degreen the peel of 'Golden Delicious' apples (Fig. 3) without concomitantly increasing flesh softening (Fig. 2) or preventing climacteric volatile production as MCP does (Fig. 6). However, heat decreased while MCP maintained titratable acidity, a good indicator of sensory acid (or sour) taste, apple flavor, and overall flavor (Harker et al., 2002b; Plotto et al., 1997, 1999; Watada et al., 1981).

Caution is advised when combining stressful treatments to inhibit ripening or decrease decay of apples during storage. In the first year of our study, fruit that had been treated with MCP were immediately heated to $38{ }^{\circ} \mathrm{C}$ for $4 \mathrm{~d}$. Most of the MCP + heat- 
treated fruit but none of the fruit that had been treated with MCP or heat alone developed a surface injury (mottled browning of the peel) during cold storage that would have precluded their use on the fresh market. In the third year of the study, MCP-treated fruit were allowed to outgas for a 7-to 8-h period before receiving the heat treatment, and these fruit showed no signs of injury. Whether the injury was prevented by having an outgassing period between the treatments or was the result of physiological variations of fruit from two different seasons is not known, but is under further investigation. While applying the heat treatment before the MCP treatment might reduce the risk of injuring the fruit, such a strategy would probably also reduce the efficacy of MCP. Heat changes epicuticular wax structure, leading to obstruction of surface cracks and other openings (Roy et al., 1994) which may reduce MCP influx and increase ethylene production; thus, there would be more ethylene to compete with less MCP for binding to the ethylene receptor. However, until the risk of fruit injury is eliminated, the strategy of combining MCP and heat treatments to obtain the beneficial effects of both treatments on fruit ripening and decay control cannot be recommended.

In conclusion, our data show that MCP as a postharvest treatment has potential to maintain quality of 'Golden Delicious' fruit intended for fresh market and processing and to reduce decay severity during cold storage. Prestorage heat also has potential to delay ripening and to decrease decay severity during storage. A complete understanding of the efficacy of MCP and heat as postharvest treatments is required for their successful commercial development.

\section{Literature Cited}

Abbott, J.A., A.E. Watada, and D.R. Massie. 1984. Sensory and instrument measurement of apple texture. J. Amer. Soc. Hort. Sci. 109:221228.

Abdi, N., W.B. McGlasson, P. Holford, M. Williams, and Y. Mizrahi. 1998. Responses of climacteric and suppressed climacteric plums to treatment with propylene and 1-methylcyclopropene. Postharvest Biol. Technol. 14:29-39.

Baritelle, A.L., G.M. Hyde, J.K. Fellman, and J. Varith. 2001.Using 1MCP to inhibit the influence of ripening on impact properties of pear and apple tissue Postharvest Biol. Technol. 23:153-160.

Bent, A.F., R.W. Innes, J.R. Ecker, and B.J. Staskawicz. 1992. Disease development in ethylene-insensitive Arabidopsis thaliana infected with virulent and avirulent Pseudomonas and Xanthomonas pathogens. Mol. Plant-Microbe Interactions 5:372-378.

Blankenship, S.M. and E.C. Sisler. 1989. 2,5-Norbornadiene retards apple softening. HortScience 24:313-314.

Blankenship, S.M. and E.C. Sisler. 1993. Response of apples to diazocyclopentadiene inhibition of ethylene binding. Postharvest Biol. Technol. 3:95-101.

Blanpied, G.D. and K.L. Silsby. 1992. Predicting harvest date windows for apples. Cornell Coop. Ext. Bul. 221.

Boller, T. 1990. Ethylene and plant-microbe interactions, p. 138-145. In: H.E. Flores, R.N. Arteca, and J.C. Shannon (eds.). Polyamines and ethylene: Biochemistry, physiology and interactions. Amer. Soc. Plant Physiol., Rockville, Md.

Fallik, E., S. Grinberg, M. Gambourg, J.D. Klein, and S. Lurie. 1996. Prestorage heat treatment reduces pathogenicity of Penicillium expansum in apple fruit. Plant Pathol. 45:92-97.

Fallik, E., D.D. Archbold, T.R. Hamilton-Kemp, J.H. Loughrin, and R.W. Collins. 1997. Heat treatment temporarily inhibits aroma volatile compound emission from Golden Delicious apples. J. Agr. Food Chem. 45:4038-4041.

Fan, X. and J.P. Mattheis. 1999. Impact of 1-methylcyclopropene and methyl jasmonate on apple volatile production. J. Agr. Food Chem. 47:2847-2853.
Fan, X., S.M. Blankenship, and J.P. Mattheis. 1999a. 1-Methylcyclopropene inhibits apple ripening. J. Amer. Soc. Hort. Sci. 124:690-695.

Fan, X., J.P. Mattheis, and S.M. Blankenship. 1999b. Development of apple superficial scald, soft scald, core flush, and greasiness is reduced by the ethylene action inhibitor MCP. J. Agr. Food Chem. 47:3063-3068. Golding, J.B., D. Shearer, S.G. Wyllie, and W.B. McGlasson. 1998. Application of 1-MCP and propylene to identify ethylene-dependent ripening processes in mature banana fruit. Postharvest Biol. Technol. 14:87-98.

Harker, F.R., J. Maindonald, S.H. Murray, F.A. Gunson, I.C. Hallett, and S.B. Walker. 2002a. Sensory interpretation of instrumental measurements 1: texture of apple fruit. Postharvest Biol. Technol. 24:225-239.

Harker, F.R., K.B. Marsh, H. Young, S.H. Murray, F.A. Gunson, and S.B. Walker. 2002b. Sensory interpretation of instrumental measurements 2: sweet and acid taste of apple fruit. Postharvest Biol. Technol. 24:241-250.

Izumi, H., A.E. Watada, and W. Douglas. 1996. Optimum $\mathrm{O}_{2}$ and $\mathrm{CO}_{2}$ atmospheres for storing broccoli florets at various temperatures. J. Amer. Soc. Hort. Sci. 121:127-131.

Itai, A., K. Tanabe, F. Tamura, and T. Tanaka. 2000. Isolation of cDNA clones corresponding to genes expressed during fruit ripening in Japanese pear (Pyrus pyrifolia Nakai): involvement of the ethylene signal transduction pathway in their expression. J. Expt. Bot. 51:11631166.

Klein, J.D. and S. Lurie. 1992. Heat treatments for improved postharvest quality of horticultural crops. HortTechnology 2:316-320.

Klein, J.D., W.S. Conway, B.D. Whitaker, and C.E. Sams. 1997. Botrytis cinerea decay in apples is inhibited by postharvest heat and calcium treatments. J. Amer. Soc. Hort. Sci. 122:91-94.

Knoester, M., L.C. van Loon, J. van den Heuvel, J. Hennig, J.F. Bol, and H.J.M. Linthorst. 1998. Ethylene-insensitive tobacco lacks nonhost resistance against soil-borne fungi. Proc. Natl. Acad. Sci. 95:19331937.

Ku, V.V.V., R.B.H. Wills, and S. Ben-Yehoshua. 1999. 1Methylcyclopropene can differentially affect the postharvest life of strawberries exposed to ethylene. HortScience 34:119-120.

Lelièvre, J-M., L. Tichit, P. Dao, L. Fillion, Y-W. Nam, J-C. Pech, and A. Latché. 1997. Effects of chilling on the expression of ethylene biosynthetic genes in Passe-Crassane pear (Pyrus communis L.) fruits. Plant Mol. Biol. 33:847-855.

Liu, F.W. 1978. Modification of apple quality by high temperature. J. Amer. Soc. Hort. Sci. 103:730-732.

Lund, S.T., R.E. Stall, and H.J. Klee. 1998. Ethylene regulates the susceptible response to pathogen infection in tomato. Plant Cell 10:371382.

Lurie, S. 1998. Postharvest heat treatments of horticultural crops. Hort. Rev. 22:91-121.

Lurie, S., E. Fallik, J.D. Klein, F. Kozar, and K. Kovacs. 1998. Postharvest heat treatment of apples to control San Jose scale (Quadraspidiotus perniciosus Comstock) and blue mold (Penicillium expansum Link) and maintain fruit firmness. J. Amer. Soc. Hort. Sci. 123:110-114.

Mitcham, B. and A. Kader. 1996. Methods for determining quality of fresh commodities. Univ. Calif. Perishable Handling Nwslt. 85.

Mullins, E.D., T.G. McCollum, and R.E. McDonald. 2000. Consequences on ethylene metabolism of inactivating the ethylene receptor sites in diseased non-climacteric fruit. Postharvest Biol. Technol. 19:155-164.

Nakatsuka, A., S. Shiomi, Y. Kubo, and A. Inaba. 1997. Expression and internal feedback regulation of ACC synthase and ACC oxidase genes in ripening tomato fruit. Plant Cell Physiol. 38:1103-1110.

Plotto, A., A.N. Azarenko, M.R. McDaniel, P.W. Crockett, and J.P. Mattheis. 1997. Eating quality of 'Gala' and 'Fuji' apples from multiple harvests and storage durations. HortScience 32:903-908.

Plotto, A., M.R. McDaniel, and J.P. Mattheis. 1999. Characterization of 'Gala' apple aroma and flavor: Differences between controlled atmosphere and air storage. J. Amer. Soc. Hort. Sci. 124:416-423.

Porat, R., B. Weiss, L. Cohen, A. Daus, R. Goren, and S. Droby. 1999. Effects of ethylene and 1-methylcyclopropene on the postharvest 
qualities of 'Shamouti' oranges. Postharvest Biol. Technol. 15:155163.

Porritt, S.W. and P.D. Lidster. 1978. The effect of pre-storage heating on ripening and senescence of apples during cold storage. J. Amer. Soc. Hort. Sci. 103:584-587.

Rosenberger, D.A. 1991. Postharvest diseases. Blue mold. Gray mold, p. 54-56. In: A.L. Jones and H.S. Aldwinckle (eds.). Compendium of apple and pear diseases. APS Press, St. Paul, Minn.

Roy, S., W.S. Conway, A.E. Watada, C.E. Sams, E.F. Erbe, and W.P. Wergin. 1994. Heat treatment affects epicuticular wax structure and postharvest calcium uptake in 'Golden Delicious' apples. HortScience 29:1056-1058.

Rupasinghe, H.P.V., D.P. Murr, G. Paliyath, and L. Skog. 2000. Inhibitory effect of 1-MCP on ripening and superficial scald development in 'McIntosh' and 'Delicious' apples. J. Hort. Sci. Biotechnol. 75:271276.

Saftner, R.A., W.S. Conway, and C.E. Sams. 1999. Postharvest calcium infiltration alone and combined with surface coating treatments influence volatile levels, respiration, ethylene production, and internal atmospheres of 'Golden Delicious' apples. J. Amer. Soc. Hort. Sci. 124:553-558.

Saftner, R.A. 1999. The potential of fruit coating and film treatments for improving the storage and shelf-life qualities of 'Gala' and 'Golden Delicious' apples. J. Amer. Soc. Hort. Sci. 124:682-689.
SAS Institute Inc. 1999. SAS OnlineDoc. version 8. SAS Inst., Cary, N.C.

Sisler, E.C., E. Dupille, and M. Serek. 1996. Effect of 1methylcyclopropene and methylenecyclopropane on ethylene binding and ethylene action on cut carnations. Plant Growth Regulat. 18:79-86.

Sisler, E.C. and M. Serek. 1997. Inhibiton of ethylene responses in plants at the receptor level: Recent developments. Physiol. Plant. 100:577582.

Song, J., M.S. Tian, D.R. Dilley, and R.M. Beaudry. 1997. Effect of 1MCP on apple fruit ripening and volatile production. HortScience 32:536.

Sutton, T.M. 1991. Bitter rot, p. 15-16.In: A.L. Jones and H.S. Aldwinckle (eds.). Compendium of apple and pear diseases. APS Press, St. Paul, Minn.

Watada, A.E., J.A. Abbott, R.E. Hardenburg, and W. Lusby. 1981. Relationships of apple sensory attributes to headspace volatiles, soluble solids, and titratable acids. J. Amer. Soc. Hort. Sci. 106: 130-132.

Watkins, C.B., J.F. Nock, and B.D. Whitaker. 2000. Responses of early, mid and late season apple cultivars to postharvest application of 1methylcyclopropene (1-MCP) under air and controlled atmosphere conditions. Postharvest Biol. Technol. 19:17-32.

Wyllie, S.G., J.B. Golding, W.B. McGlasson, and M. Williams. 1998. The relationship between ethylene and aroma volatiles production in ripening climacteric fruit. Dev. Food Sci. 40:375-384. 